PHILIP CASS is reviews editor of Pacific Journalism Review.

\section{Media must build and retain trust}

A Day Like Today, by John Humphrys. London, UK: William Collins, 2019. 400 pages. ISBN 9780007415595

OHN HUMPHRYS will be less
well known outside the UK than his contemporary from BBC World, John Simpson, but his autobiography is an entertaining and informative recounting of his career and well worth reading.

For more than three decades he presided over BBC Radio 4's flagship early morning current affairs programme, Today. Like Jeremey Paxman on BBC2's Newsnight, he built a reputation for taking no prisoners in interviews and for having a keen sense of what makes good radio journalism.

His background, however, was in the hardscrabble of the local press in Wales and it was in Wales that he made his name for his coverage of the Aberfan disaster when, in October 1966, a wall of waste that had been dumped on top of a hillside came roaring down the valley and obliterated the mining village, killing 116 children.

Eventually joining BBC television, he became an overseas correspondent, reporting on the horrors of apartheid and the end of white rule in what was then Rhodesia. He also worked in the

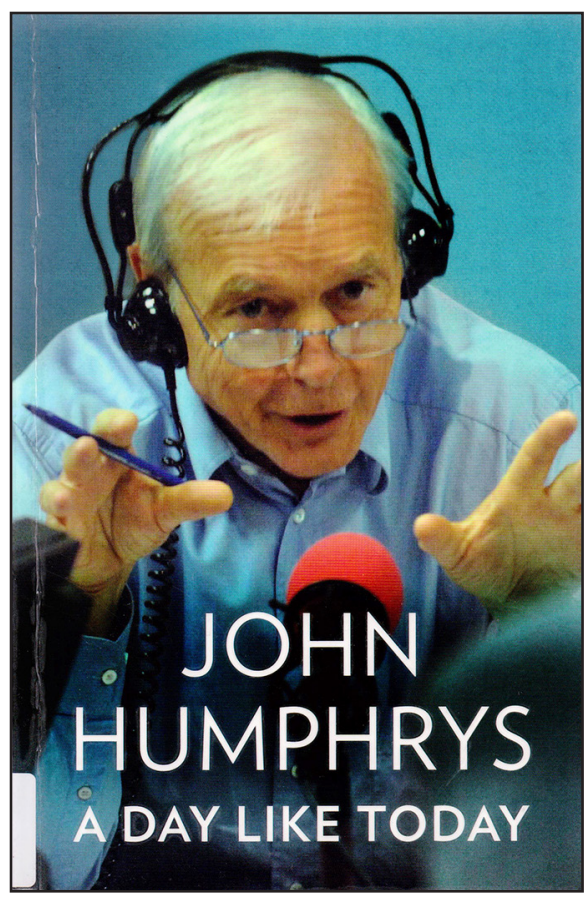

US at the height of the Watergate scandal and was lucky to have a tip-off that Nixon was going to announce his resignation, a lead that allowed him to book satellite time for a live feed to London when such things were considered a monstrous extravagance.

Then he and Simpson were offered jobs as news presenters. It was a disaster. Simpson went off to the BBC World service and Humphrys dived at the chance to front Today.

There may be a certain romance in his reminiscences of the joys of getting up in the middle of the night so he could be in the studio sounding bright and cheerful at dawn. At least he acknowledges the burden that falls on the overnight editorial team who need to have stories prepared for the presenters. 
For people outside the UK, Humphrys is probably best known for the story which led to the apparent suicide of Dr David Kelly after another BBC reporter alleged on air that the Blair government had cooked the books in its claims that Saddam Hussein had weapons of mass destruction.

Tony Blair was not somebody Humphrys liked and even less so his rottweiler of a press secretary, Alastair Campbell, who constantly attacked the $\mathrm{BBC}$ and went into overdrive when Today first revealed what today everybody takes for granted - that the leaders of those countries most involved in the invasion of Iraq - the US, the UK and Australia - lied through their teeth to justify what became a military and political catastrophe.

A constant theme underlying
Humphrys' memoir is the need for the public to have a reliable source of information in which they can place their trust. As one would expect, he takes some Parthian shots at the BBC, particularly for its handling of the child abuse scandals, of which Jimmy Saville was the most famous and its part in creating a distrust of the political system which alienates voters and, in the US, helped elect Trump.

In the end, though, he says the BBC's job is to 'build and retain trust. For all its weaknesses and failings, that is what the $\mathrm{BBC}$ has been doing for the best part of a century. And if that sounds absurdly simplistic ... so be it. The key is always trying to separate fact from speculation and never to pretend to be privy to some great truth denied to others.'

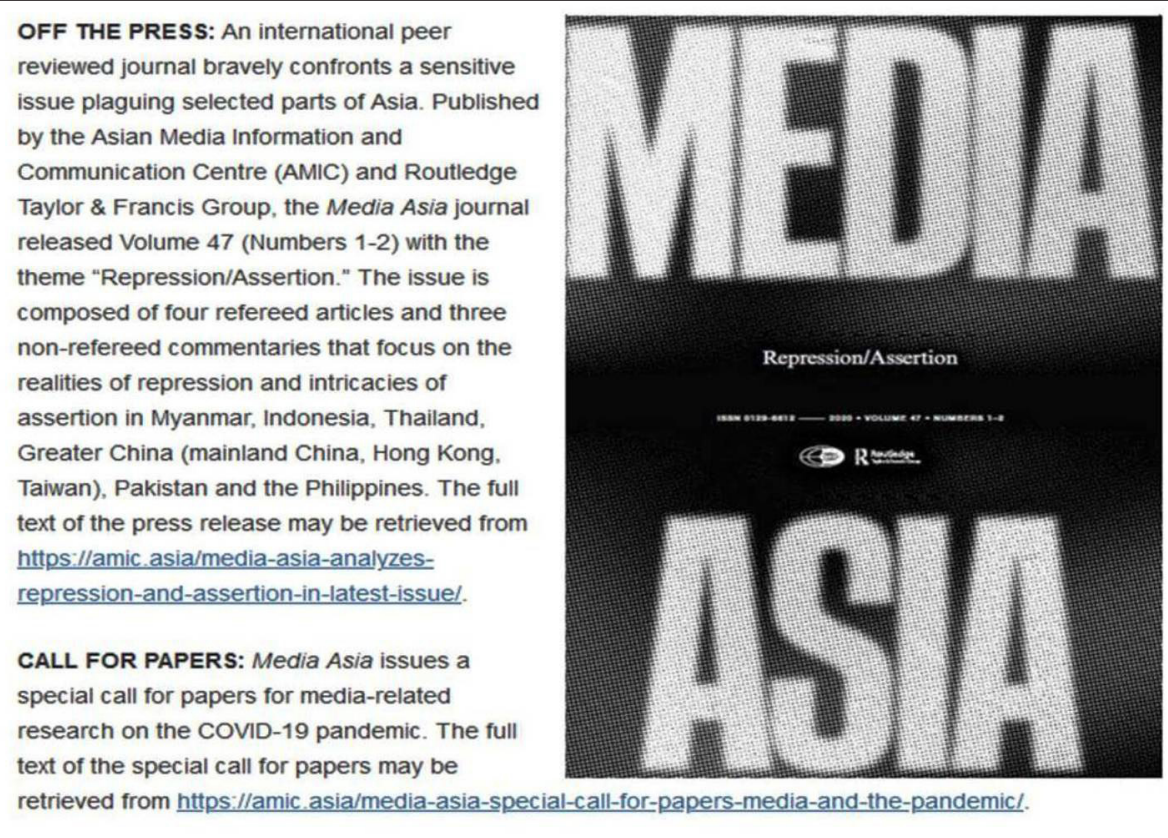

